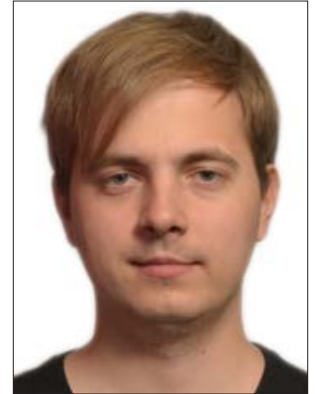

Artem

V. Krylov

Крилов

Артем

Вадимович

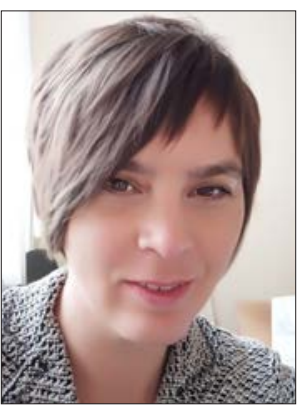

Yuliia

S. Yamnenko

Ямненко

Юлія Сергіївна

УДК 519.852 .33

\title{
SOLUTION OF THE TRANSPORT PROBLEM BY ARTIFICIAL INTELLIGENCE FOR MARITIME TRANSPORT
}

\section{РІШЕННЯ ТРАНСПОРТНОЇ ЗАДАЧІ ЗА ДОПОМОГОЮ ШТУЧНОГО ІНТЕЛЕКТУ ДЛЯ МОРСЬКОГО ТРАНСПОРТУ}

DOI https:// doi.org/10.15589/smi2019.1(11).14

\author{
Artem V. Krylov
}

Yuliia S. Yamnenko

\author{
Крилов Артем Вадимович, аспірант, \\ кафедра промислової електроніки \\ artem142142@gmail.com \\ ORCID 0000-0002-7203-300X
}

Ямненко Юлія Сергіївна, докт. техн. наук, проф., завідувач кафедри промислової електроніки ORCID 0000-0002-9796-6420

Igor Sikorsky Kyiv Polytechnic Institute, Kyiv

Київький політехнічний інститут імені Ігоря Сікорського, м. Київ

Abstract. The purpose of this work is to solve the transport problem for sea freight using the Mashine Learning algorithms. An important task related to the work of transport is the organization of freight. In particular, the maritime freight network is a large, complex system whose modeling is compounded by additional difficulties due to the complexity of route maps and the variety of ship traffic. When investigating the characteristics of the sea freight system, it is generally advisable to use coarse models that introduce significant approximations and do not take into account a number of details. At the same time, a detailed study of isolated sections of the network uses an exact model, in which the connections of this area with others are not actually considered, but this area is explored in detail. In this case, one should not overlook the deviation of the model from the real network in the first case and the consequences of ignoring the linkages of the plots in the second. Building a model that accurately takes into account and describes all the details leads to an unreasonable complication of the design process, so in practice, the simulation always uses a number of assumptions and approximations of the real characteristics of the movement of ships, depending on the specific task. Four models are used to build an optimal cargo transportation system: the Transnational Cargo Model; Model of cargo transportation with dedicated initial port of departure of cargo; Model of cargo transportation with dedicated initial ports of departure and final port of cargo distribution; Model of cargo transportation on a circular chain of ports. Describe the route through n-ports using n-dimensional differential equations. The route conditions are given by the traveling wave equation. On the basis of these calculations the optimal route of movement of cargo ships is built. Conditions affecting freight traffic include: number of ports, quantity of fuel, final port of cargo, as well as distances between ports and intermediate ports. The scientific novelty is that the role of the person is reduced only to the observer of the system, which will simplify the calculations for freight, as well as help reduce the cost of fuel and human costs.

Key words: transport task, port, traveling wave equation, optimization, machine learning.

Анотація. Метою цієї роботи є вирішення транспортної задачі для вантажного морського транспорту з використанням алгоритмів Mashine Learning. Важливим завданням, пов'язаним з роботою транспорту, є організація вантажоперевезень. Зокрема, мережа морських вантажоперевезень являє собою велику складну систему, моделювання якої пов'язане з додатковими труднощами через складність маршрутних карт і різноманіття руху кораблів. Методика. Під час дослідження характеристик системи морських вантажоперевезень загалом доцільно використовувати грубі моделі, в які вводяться істотні апроксимації, а низка деталей не враховується. Водночас у разі детального дослідження ізольованих ділянок мережі використовується точна модель, в якій зв'язки такої ділянки 3 іншими фактично не розглядаються, але детально досліджується ця ділянка. При цьому не слід випускати з уваги відхилення моделі від реальної мережі в першому випадку і наслідки неврахування зв'язків ділянок у другому. Побудова моделі, яка точно враховує та описує всі деталі, веде 
до необгрунтованого ускладнення процесу іï проєктування, тому на практиці під час моделювання завжди використовується низка припущень та апроксимацій реальних характеристик руху кораблів залежно від конкретної задачі. Для побудови оптимальної системи вантажоперевезень використовується чотири моделі: модель транснаціональних вантажоперевезень; модель вантажоперевезень з виділеним початковим портом відправлення вантажів; модель вантажоперевезень з виділеними початковими портами відправлення і кінцевим портом розподілу вантажів; модель вантажоперевезень по круговому ланцюжку портів. Результати. Результатом статті є опис маршруту через n портів з проміжними портами через n-вимірні диференційні рівняння. Умови маршруту задаються рівнянням біжучої хвилі. На базі цих розрахунків будується оптимальний маршрут руху вантажних кораблів. До умов, що впливають на вантажоперевезення, належать: кількість портів, кількість палива, кінцевий порт вантажу, а також відстані між портами й проміжними портами. Наукова новизна. Наукова новизна полягає в тому, що роль людини зводиться лише до спостерігача за системою, що дасть змогу спростити розрахунки для вантажоперевезень. Практична значимість. Така модель допоможе скоротити витрати на пальне й людські затрати у морських вантажоперевезеннях.

Ключові слова: транспортна задача, порт, рівняння біжучої хвилі, оптимізація, машинне навчання.

\section{References}

[1] Kantorovych, L.V. (1939). Matematycheskye metodi orhanyzatsyy y planyrovanyia proyzvodstva. Leningrad: Yzd-vo LHU, $68 \mathrm{~s}$.

[2] Kantorovych, L.V., Havuryn, M.K. (1949). Prymenenye matematycheskykh metodov v voprosakh analyza hruzopotokov. Problemi povishenyia effektyvnosty raboti transporta: Sb. nauchn. statei. Moskva: Yzd-vo AN SSSR, S. $110-138$.

[3] Dantsyh, Dzh., Volf, F. (1964). Alhorytm razlozhenyia dlia zadach lyneinoho prohrammyrovanyia - Matematyka: Sb. perevodov, 1964. T. 8. No 1. S. 151-160.

[4] Lure, A.L. (1962). Alhorytm reshenyia setevoi transportnoi zadachy s ohranychenyem propusknikh sposobnostei metodom uslovno-optymalnikh planov - Mat-li Konf. po opitu y perspektyvam prymenenyia matematycheskykh metodov y EMM v planyrovanyy. S. 3-13.

[5] Aven, O.Y., Lovetskyi, S.E., Moyseenko, H.E. (1985). Optymyzatsyia transportnikh potokov. Moskva: Nauka, 166 s.

[6] Halaburda, V.H. (1985). Optymalnoe planyrovanye hruzopotokov. Moskva: Transport, 256 s.

[7] De Jong, G., Gunn, H.F., Walker, W. (2004). National and international freight transport models: Anoverview and ideas for further development - Transport Rev., Vol. 24. No. 1. Pp. 103-124.

[8] Beklaryan, L.A., Khachatryan, N.K. (2006). Traveling wave type solutions in dynamic transport models. Functional Differential Equations, Vol. 13. No. 2. Pp. 125-155.

[9] Yamada, T., Russ, B.F., Castro, J., Taniguchi, E. (2009). Designing multimodal freight transport networks: A heuristic approach and applications. Transportation Sci., Vol. 43. No. 2. Pp. 129-143.

[10] Levyn, D.Iu. (2010). Modelyrovanye protsessov perevozky. Myr transporta, T. 8. No 5(33). S. 48-55.

[11] Beklarian, L.A., Khachatrian, N.K. (2013) Ob odnom klasse dynamycheskykh modelei hruzoperevozok. Zhurnal vichyslytelnoi matematyky y matematycheskoi fyzyky, T. 53. No 10. S. 1649-1667.

\section{ВСТУП}

Постановка задачі й відокремлення не вирішених раніше частин загальної проблеми. Ця робота присвячена дослідженню процесу організації вантажоперевезень у морському транспорті, позаяк процес інтелектуального перевезення є актуальним нині. Будемо розглядати задачу побудови і дослідження динамічної моделі організації вантажоперевезень на видовженій ділянці шляху з великою кількістю проміжних точок зупинок, через які проходить вантажопотік. Передбачається, що між початковими і кінцевими точками є міжпортовий перегінний шлях, де тимчасово може зберігатися частина вантажів. Мета роботи - створення моделі автономної побудови маршруту вантажоперевезень морського транспорту.

Аналіз останніх досліджень і публікацій. Серед проблем, пов'язаних 3 роботою транспорту, центральне місце посідають завдання планування та організації вантажоперевезень. Перші дослі- дження, присвячені розробці оптимального плану перевезень, проводилися у 1930-х рр. У 1939 р. Л.В. Канторовичем математично описана транспортна задача лінійного програмування [1]. У його роботах визначено клас задач, близьких до транспортної, запропонований алгоритм для вирішення транспортної задачі, названий методом дозвільних множників. У 1949 р. Л.В. Канторович і М.К. Гавурін опублікували роботу, в якій вирішувалася транспортна задача $з$ обмеженнями на пропускні спроможності. Використовуючи ідеї загального методу Л.В. Канторовича, для вирішення завдань лінійного програмування був розроблений метод потенціалів [2]. Через рік аналогічний метод був запропонований Дж. Данцигом і Ф. Вольфом [3].

Радянським вченим А.Л. Лур'є був запропонований метод вирішення транспортної задачі шляхом наближення умовно-оптимальних планів [3]. У 1985 р. О.І. Авен, С.С. Ловецький і Г.С. Моісеєнко опублікували роботу, присвячену проблемам оптимального планування й управління транспортними 
потоками на транспортних мережах [2]. У цій роботі були розглянуті математичні моделі транспортних мереж і транспортних потоків.

Але натепер не було розглянуто рішення транспортної задачі для морських вантажоперевезень за допомогою інтелектуального навчання.

Методи, об'єкт та предмет дослідження. Загалом є 4 основні моделі вантажоперевезень:

- модель транснаціональних вантажоперевезень;

- модель вантажоперевезень з виділеним початковим портом відправлення вантажів;

- модель вантажоперевезень 3 виділеними початковими портами відправлення і кінцевим портом розподілу вантажів;

- модель вантажоперевезень по круговому ланцюжку портів.

На рис.1 наведено схему вантажоперевезень транспортної задачі.

Використання того чи іншого типу моделі залежить від конкретної ситуації - кількості та географічного розташування портів, часу транспортування тощо. Точністю оптимізації відрізняється тільки 1-ий тип, позаяк за невизначених умов дуже важко оптимізувати вантажопотік. Далі розглянемо наведені моделі вантажоперевезень більш детально [1].

1. Модель транснаціональних вантажоперевезень

Така модель описує рух вантажопотоку без виділених початкових портів відправлення і кінцевого порту розподілу вантажів, внаслідок чого вважаємо, що число проміжних портів нескінченно в обидва боки. Робота всіх портів складається з прийому, обробки та відправки вантажів, а самі порти мають задану пропускну здатність [2].

Обробка вантажів відбувається у вузлах портів. У кожному вузлі протягом одиниці часу обробляється одиничний обсяг вантажів. Позначимо кількість задіяних вузлів n-го порту у момент часу $\mathrm{t}_{\mathrm{k}}$ через $\mathrm{z}_{\mathrm{n}}\left(\mathrm{t}_{\mathrm{k}}\right)$. Очевидно, що кількість задіяних вузлів оброб- ки вантажів за безперебійної роботи всього ланцюга перевезень обмежена.

Під пропускною здатністю порту $\Delta$ будемо розуміти максимальну кількість вузлів, в яких відповідно обробляється максимальний обсяг вантажів за одиничний інтервал часу.

Організація подібних вантажопотоків залежить від технологій приймання, обробки та відправлення вантажів. Перша технологія заснована на встановлених нормативних правилах взаємодії сусідніх портів. Для кожного порту з номером $i є$ правила взаємодії 3 попереднім (i-1)-м портом і наступним (i+1)-м портом. Згідно з правилом взаємодії з попереднім портом [4], порт з номером $і$ збільшує кількість задіяних вузлів з інтенсивністю $\alpha\left(\mathrm{z}_{\mathrm{i}-1}-\mathrm{z}_{\mathrm{i}}\right)$, якщо кількість задіяних вузлів у ньому менша, ніж у попередньому порту. При цьому вантажопотік приймається з попереднього порту. В іншому разі порт з номером $i$ зменшує кількість задіяних вузлів з такою ж інтенсивністю, i вантажопотік відправляється на перегінний шлях.

Згідно $з$ правилом взаємодії з наступним портом [5], порт з номером $i$ зменшує кількість задіяних вузлів 3 інтенсивністю $\alpha\left(\mathrm{z}_{\mathrm{i}-1}-\mathrm{z}_{\mathrm{i}+1}\right)$, якщо кількість задіяних вузлів у ньому більша, ніж у наступному порту. При цьому вантажопотік відправляється у наступний порт. В іншому разі порт з номером $i$ збільшує кількість задіяних вузлів з такою ж інтенсивністю, і вантажопотік приймається 3 перегінного шляху.

Перша технологія не враховує умову обмеженості пропускної спроможності порту. Крім того, вона не дає змогу використовувати весь потенціал порту.

Друга технологія дає змогу як збільшувати кількість задіяних вузлів (якщо вона менше $\Delta$ ), так і зменшувати (якщо вона перевищує $\Delta$ ). При цьому вантаж приймається з перегінного шляху або відправляється на перегінний шлях. Функція $\varphi(\cdot)$, що задає швидкість зміни кількості задіяних вузлів у рамках другої технології, має вигляд, зображений на рис. 2.

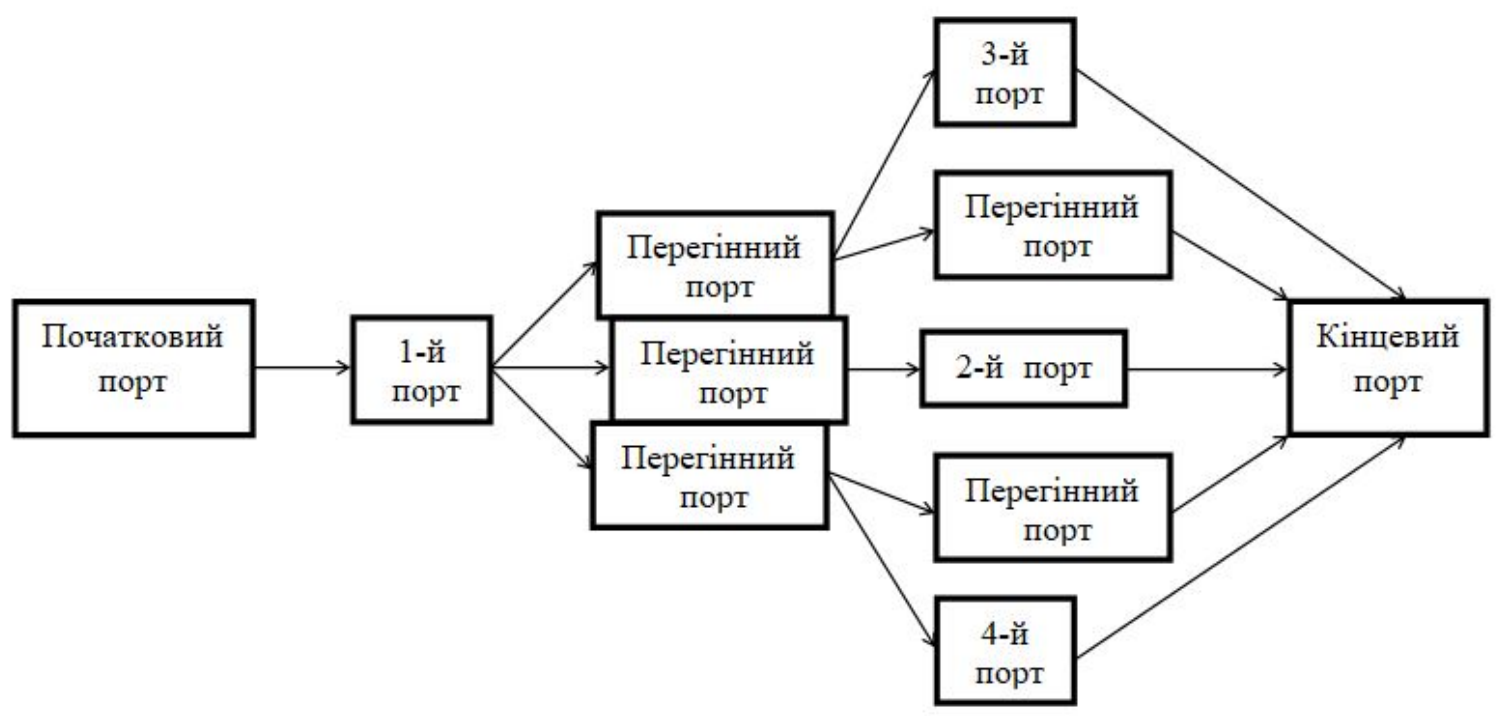

Рис. 1. Схема вантажоперевезень транспортної задачі 


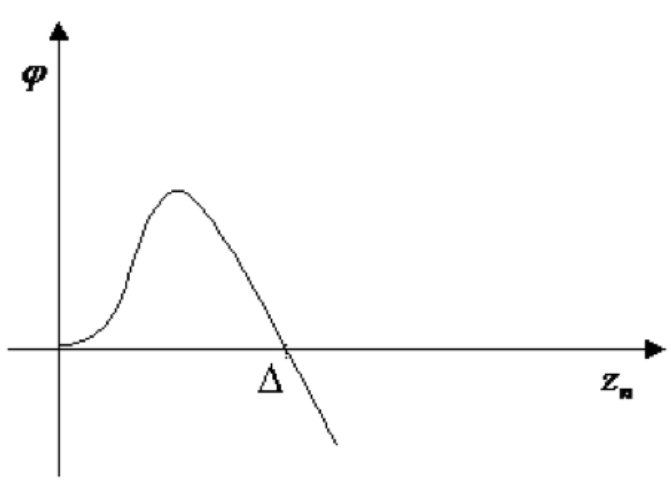

Рис. 2. Швидкість зміни числа задіяних вузлів (друга технологія)

Таким чином, з урахуванням роботи першої та другої технологій швидкість зміни числа задіяних вузлів для $i$-го порту буде описуватися диференціальним рівнянням:

$$
\dot{z}_{l}(t)=\alpha\left(z_{i-1}-z_{i}\right)-\alpha\left(z_{i}-z_{i+1}\right)+\varphi\left(z_{i}\right), \quad i \in Z, t[0,+\infty) .
$$

Ефективне перевезення вантажів вимагає наявності дієвої і простої системи контролю. Вона полягає в тому, що обсяги оброблюваних вантажів для планового інтервалу часу мають збігатися з обсягом роботи у всіх портах, єдиним для всіх портів. Цю умову можна описати таким чином: $\epsilon$ число $\tau>0$, яке залежить від $t$ та $i$, таке, що для всіх $i \in \mathrm{Z}$ i $t \in[0,+\infty)$ виконується рівність:

$$
z_{t}(t)=z_{i+1}(t+\tau)
$$

Рішення системи диференціальних рівнянь (1), що задовольняють умові (2), називаються рішеннями типу біжучої хвилі [6]. Константу $\tau$, яка є зсувом між моментами вимірів і порівняння обсягів вантажів, будемо називати характеристикою системи контролю. Таким чином, така модель, що описує процес вантажоперевезень і їх систему контролю, задається системою диференціальних рівнянь і умовою, яка задає біжучу хвилю:

$$
\begin{gathered}
\dot{z}_{l}(t)=\alpha z_{i-1}-2 \alpha z_{i}+\alpha z_{i+1}+\varphi\left(z_{i}\right), \quad i \in Z, t \in[0,+\infty) . \\
z_{i}(t)=z_{i+1}(t+\tau), \quad i \in Z, t \in[0,+\infty) .
\end{gathered}
$$

Сімейство неперервних функцій $\left\{\mathrm{z}_{\mathrm{i}}(\cdot)\right\} \mathrm{i} \in \mathrm{Z}$, визначених на $[0,+\infty), \epsilon$ рішенням системи диференціальних рівнянь (3), якщо при всіх $t \in[0,+\infty)$ функції $\mathrm{z}_{\mathrm{i}}(\cdot)$ задовольняють цій системі [5].

Для $\mu \in(0,1)$ визначимо простір функцій $з$ вагами:

$$
\begin{gathered}
\vartheta_{\mu}^{1} C^{(k)}(R)=\left\{x(\cdot): x(\cdot) \in C^{(k)}(R, R), \begin{array}{c}
\max \sup \\
0 \leq r \leq k, t \in R
\end{array} x^{x^{(r)}(t) e^{-\delta||}{ }_{R}<+\infty}\right\}, \\
k=0,1, \ldots, \mu=e^{-\delta}
\end{gathered}
$$

і нормою:

$$
x_{\mu}^{(k)}=\underset{0 \leq r \leq k, t \in R^{(r)}(t) e_{R}^{-\delta|t|},}{\max \sup }
$$

а також векторний простір
$K^{-1}=\Pi_{-\infty}^{+\infty} R_{i}, R_{i}=R, i \in Z$ з елементами

$X=\left\{x_{i}\right\}_{-\infty}^{+\infty}, x_{i} \in R, i \in Z$, і зі стандартною топологією повного прямого добутку.

На рис. 3 наведено функції $\mu_{1}(\tau) m a \mu_{2}(\tau)$.

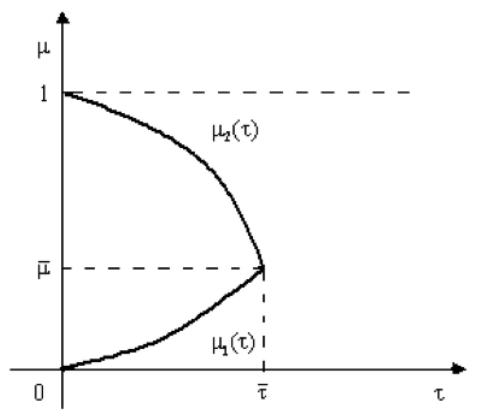

Рис. 3. Функції $\mu_{1}(\tau)$ та $m a \mu_{2}(\tau)$.

У просторі $\mathrm{K}^{-1}$ визначимо сімейство гільбертових підпросторів

$$
K_{2 \mu}^{1}=\left\{X: X \in K^{-1} ; \sum_{i=-\infty}^{+\infty}\left|x_{i}\right|_{R}^{2} \mu^{2|i|}<+\infty\right\}, \mu \in(0,1),
$$

3 нормою

$$
X_{2 \mu}=\left[\sum_{i=-\infty}^{+\infty}\left|x_{\mathrm{i}}\right|_{R}^{2} \mu^{2|i|}<+\infty\right]^{1 / 2} .
$$

Позначимо

$$
M(\tau)=\tau \max \left[2 \alpha, L_{0}\right]
$$

і розглянемо нерівність щодо двох змінних

$$
\begin{gathered}
\tau \in(0,+\infty) \operatorname{ma} \mu \in(0,1) \\
M(\tau)\left[1+2 \mu^{-1}\right]<\ln \mu^{-1}, \quad \mu \in(0,1) .
\end{gathered}
$$

Множина рішень нерівності (5) описується функціями $\mu_{1}(\tau)$ ma $\mu_{2}(\tau)$, зображено на рис. 3 .

Тобто для початкових даних а $>0, \bar{i} \in Z$, початкового моменту часу $\bar{t} \in[0,+\infty) i$ характеристик $\tau$, задовольняючих умову $0<\tau<\bar{\tau}, \epsilon$ рішення $\left\{Z_{i}(\cdot)\right\}_{i \in Z}$ рівняння (3) типу біжучої хвилі (умова (4)) 3 характеристикою $\tau$, задовольняючи початкову умову $Z_{\bar{i}}(\bar{t})=a . \mathrm{У}$ такому рішенні для будь-якого $i \in Z$ функція $Z_{i}(\cdot)$ належить простору $L_{\sqrt[\tau]{\mu}}^{1} C^{(0)}([0,+\infty))$ при $\mu \in\left(\mu_{1}(\tau), \mu_{2}(\tau)\right)$. Таке рішення є єдиним $\mathrm{i}$ неперервно залежить від початкової умови $a$, де кожна координата $Z_{i}(\cdot), \mathrm{i} \in Z$, неперервно залежить від початкової умови $a$ як елемент простору $L_{\sqrt[\tau]{\mu}}^{1} C^{(0)}([0,+\infty))$.

Система (3)-(4) має два стаціонарні рішення типу біжучої хвилі:

$$
\overline{Z_{1}} \equiv\{\ldots, 0,0,0, \ldots\}, \overline{Z_{2}} \equiv\{\ldots, \Delta, \Delta, \Delta, \ldots\} .
$$

Очевидно, що такі рішення належать простору $K_{2 \propto}^{1}$ при $\mu \in(0,1)$. 
Стаціонарне рішення $\bar{Z}=\left\{\bar{Z}_{i}\right\}_{i \in Z}$ системи рівнянь (3) у фазовому просторі $K_{2 \propto,}^{1}, \mu \in(0,1) \in$ стійким по Ляпунову, якщо існує $\gamma>0 u \bar{t} \geq 0$ такі, що для $\mathrm{d} \in K_{2 \mu}^{1}$, задовольняє умову $d-\bar{z}_{2 \mu}<\gamma$, рішення $\mathrm{Z}(\mathrm{t})$ рівняння (3) з початковою умовою $Z(\bar{t})=d$ існує; для $\varepsilon>0$ iснує $0<\sigma_{1}<\gamma$ таке, що при $d-\bar{z}_{2 \mu}<\sigma_{1}$, рішення $\mathrm{Z}(\mathrm{t})$ рівняння (3) з початковою умовою $Z(\bar{t})=d$ задовольняє умову $d-\bar{z}_{2 \mu}<\varepsilon$ для всіх $t>\bar{t}$.

Тоді стійке за Ляпуновим стаціонарне рішення $\bar{Z}=\left\{\bar{Z}_{i}\right\}_{i \in Z}$ системи рівнянь (3) у фазовому просторі $K_{2 \mu}^{\mathrm{j} \in Z}, \mu \in(0,1) \epsilon$ асимптотично стійким, якщо $\lim Z(t)-\bar{Z}_{2 \mu}=0$.

Визначимо:

$$
\tau_{\max }=\sup \left\{\tau: \tau \leq \tau, \mu_{2}(\tau) \geq \bar{\partial}\right\} .
$$

На інтервалі $\left(0, \tau_{\max }\right]$ визначається функція $\partial(\tau)=\max \left(\bar{\partial}, \mu_{1}(\tau)\right)$, графічно зображена на рис. 4 (при $\tilde{\partial}<\bar{\mu}$ на рис. 4 , а й при $\tilde{\partial}>\bar{\mu}$ на рис. $4, \sigma$ ).

3 цього випливає, що для того, щоб стаціонарне рішення $\bar{z}=\left\{\overline{z_{i}}\right\}_{i \in Z}, \quad \overline{z_{i}}=\overline{z_{i+1}}, \mathrm{i} \in Z$ типу біжучої хвилі системи рівнянь (3) у фазовому просторі $K_{2 \propto}^{1}$, $\mu \in(0,1)$ було рішенням транспортної задачі транснаціональної моделі, й виконувалися умови:

- воно стійке за Ляпуновим;

- існують такі $\gamma>0$ it $\geq 0$, що для числа $\mathrm{d}_{0}$, задовольняючого умову $\left|d_{0}-\bar{z}_{0}\right|<\gamma, \quad$ рішення $z(t)=\left\{z_{n}(t)\right\}_{n \in Z}$ системи (3)-(4) 3 початковою умовою $z_{0}(\bar{t})=d_{0}$

- для $\varepsilon>0$ існують $0<\sigma_{2}<\gamma$ такі, що 3 умови $\left|d_{0}-\bar{z}_{0}\right|<\sigma_{2}$ витікає, що рішення $\mathrm{z}(\mathrm{t})$ системи (3)(4) 3 початковою умовою $z_{0}(\bar{t})=d_{0}$ задовольняють умову $\left\|z(t)-\bar{z}_{2 \mu}\right\|<\varepsilon$ для всіх $\mathrm{t}>\bar{t}$ [6].

2. Модель вантажоперевезень 3 виділеним початковим портом відправлення вантажів

Така модель характеризується виділеною початковою точкою відправлення вантажів. Тоді модель матиме стаціонарний порт $i=0$ і декілька проміжних портів $i=1,2, .$. Як і у першій моделі, організація вантажопотоку здійснюється за допомогою двох технологій.

Перша технологія. У портах з номерами $i=1,2 \ldots$ діє перша технологія, описана в першій моделі. У по- чатковому порті $i=0$ перша технологія визначається за допомогою правила взаємодії з наступним портом і описується функцією $\psi(\mathrm{t})$, залежною від часу $t \geq 0$. Припускаємо, що функція $\psi(\cdot) \in$ кусково-неперервно-диференційованою. Оскільки початкова точка $є$ вузловою, то можна припустити, що вона має досить велику потужність, щоб за необхідності на ній можна було залучити більшу кількість задіяних вузлів, чого не можна зробити на проміжних точках [7].

Друга технологія. Для точок з номерами $i=1,2 \ldots$ друга технологія в точності повторює другу технологію з першої моделі. Для початкового порту $i=0$ друга технологія $з$ попередньої моделі використовується для розвантаження, тому швидкість зміни числа задіяних вузлів обробки в початковому порту в рамках другої технології описується функцією $\varphi_{0}(t)$, яка залежить від кількості задіяних вузлів у початковому порту і задовольняє таким умовам:

- на півпрямій $(-\infty, \Delta]$ тотожно дорівнює нулю;

- на півпрямій $[\Delta,+\infty) \epsilon$ спадаючою функцією.

Припустимо, що функції $\varphi_{0}(\cdot) \mathrm{i} \varphi(\cdot)$ (визначені в першій моделі) $є$ нескінченно диференційованими. Очевидно, що якщо об'єм вантажу в 0-му порті не перевищує $\Delta$, використовується тільки перша технологія.

Таким чином, 3 урахуванням роботи першої i другої технологій процес вантажоперевезень описується системою диференційних рівнянь:

$$
\left\{\begin{array}{c}
\dot{z}_{0}(t)=\psi(t)-\alpha z_{0}+\alpha z_{1}+\varphi_{0}\left(z_{0}\right), t \in[0,+\infty) ; \\
\dot{z}_{i}(t)=\alpha z_{i-1}-2 \alpha z_{i}+\alpha z_{i+1}+\varphi\left(z_{i}\right), i=1,2, \ldots, t \in[0,+\infty) ; \\
z_{i}(t)=z_{i+1}(t+\tau), i=0,1,2, \ldots t \in[0,+\infty) .
\end{array}\right.
$$

Клас рішень системи (7) надзвичайно вузький, тому для описання реалізовуваних режимів вантажоперевезень використовується більш широкий клас рішень, які називаються квазі-рішенням типу біжучої хвилі. Ці рішення є кусково-абсолютно-неперервними, а розриви розташовані в точках(портах), кратних характеристикам системи контролю (параметр $\tau$ ).

Для початкових даних а $>0 \quad \bar{i} \in\{0,1, \ldots\} i$ початкового моменту часу $\bar{t} \in[0,+\infty)$, описує всі $\tau$, які задовольняють умову $0<\tau<\bar{\tau}$ (рис. 2 ) і функцій

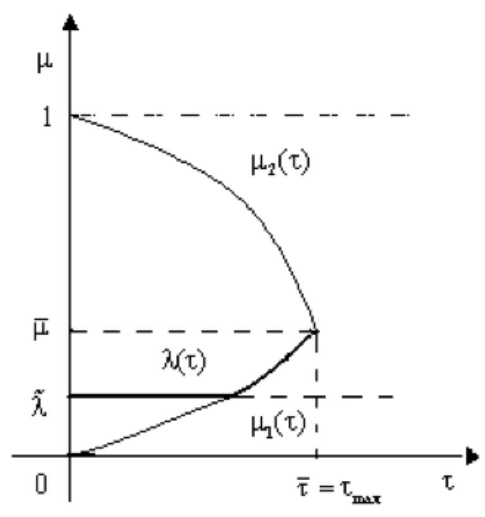

(a)

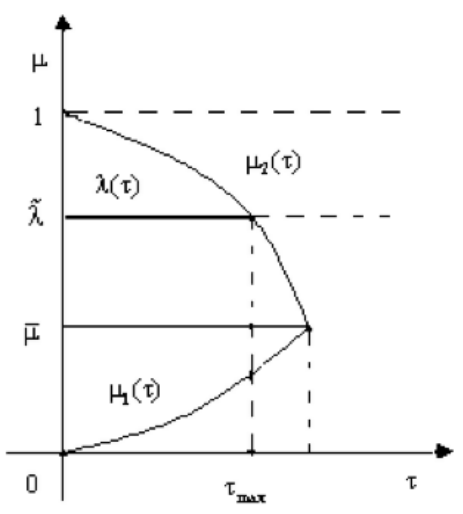

(б)

Рис. 4. Функція $\partial(\tau):($ a) $\tilde{\partial}<\bar{\mu} ;$ (б) $\tilde{\partial}>\bar{\mu}$ 
$\psi(\cdot) \in C^{\infty}([0, \tau], R)$ на півпрямій $\left(\tau,+^{\circ}\right)$ існує єдине кусково-неперервне подовження функції $\psi(\cdot)$ і відповідне йому квазі-рішення $\left\{z_{i}(\cdot)\right\}_{0}^{+\infty}$ типу біжучої хвилі 3 характеристикою $\tau$ системи (7) у фазовому просторі $K_{2 \propto}^{1}, \mu \in\left(\mu_{1}(\tau), \mu_{2}(\tau)\right)$, що задовольняє початковій умові $z_{\bar{i}}(\bar{t})=a$. Таке квазі-рішення є єдиним, неперервно залежить від початкової умови $a$ і функції $\psi(\cdot)$.

Це означає, що в усіх портах у моменти часу, кратні характеристиці контролю, необхідно різко змінювати кількість задіяних вузлів. Така процедура потребує підключення додаткових потужностей, які $є$ тільки у вузловому початковому порті. Для цього досить лише в початковому порті в початковий момент часу різко змінити кількість задіяних вузлів (змінити функцію $\psi(\bullet)$ в нормі $\mathrm{L}_{1}([0, \tau], \mathrm{R})$, щоб організувати контрольований вантажообіг за допомогою визначених технологій (отримати так зване $\varepsilon$-квазі-рішення, тобто таке квазі-рішення, у якого вказані розриви менші $\varepsilon$ ). Квазі-рішення типу біжучої хвилі з характеристикою $\tau$ називається $\varepsilon$ - квазі-рішення типу біжучої хвилі з характеристикою $\tau$ чи $(\varepsilon, \tau)$-квазі-рішенням, якщо виконуються нерівності:

$$
\left|z_{0}(k \tau-0)-z_{0}(k \tau+0)\right|<\varepsilon, k=1,2 \ldots
$$

Для початкових даних а>0, $\bar{i} \in\{0,1, \ldots\}$, початкових моментів часу $\bar{t} \in[0,+\infty)$, характеристик $\tau$, задовольняючих умові $0<\tau<\bar{\tau}$, довільної функції $\psi(\diamond) \in C^{\infty}([0, \tau], R)$ і довільного $\varepsilon>0$ існує функція $\psi_{\varepsilon}(\cdot) \in C^{\infty}([0, \tau], R)$, відмінна від $\psi(\cdot)$ в околі точки 0 така, що іiі продовження на $\left(\tau,+^{\circ}\right)$ та відповідне йому квазі-рішення $\left\{z_{i \varepsilon}(\cdot)\right\}_{0}^{+\infty}$ типу біжучої хвилі з характеристикою $\tau$ системи (7), задовольняе початковій умові $z_{\bar{i} \varepsilon}(\bar{t})=a$, належить фазовому простору $K_{2 \propto}^{1}$ при $\mu \in\left(\mu_{1}(\tau), \mu_{2}(\tau)\right)$ і $\epsilon(\varepsilon, \tau)$-квазірішенням моделі вантажоперевезень 3 виділеним початковим портом відправлення вантажів [8].

3. Модель вантажоперевезень 3 виділеними початковими портами відправлення і кінцевим портом розподілу вантажів

Модель вантажних перевезень 3 початковим портом відправлення вантажу $i=0, \quad$ кінцевою кількістю проміжних портів $i=1,2, \ldots, m$ та кінцевим портом розподілу вантажів $i=m+1$. Так само, як і в попередніх моделях, організація вантажопотоку здійснюється за допомогою двох технологій.

Перша технологія. У портах 3 номерами $i=0,1,2, \ldots, m$ діє технологія описана раніше в моделі вантажоперевезень з виділеним початковим портом відправлення вантажів. Технологія подачі вантажів на початковий порт описується функцією $\psi_{1}(t), t \geq 0$. У кінцевому порту перша технологія визначається за допомогою правила взаємодії 3 попереднім портом і описується функцією $\psi_{2}(t), t \geq 0$. При цьому припускається, що функція $\psi_{1}(\cdot)$ є кусковонескінченно-диференційованою, а функція $\psi_{2}(\cdot)-$ кусково-неперервною.

Друга технологія. Для початкового і проміжних портів друга технологія в точності повторює другу технологію, описану в двох попередніх моделях. Друга технологія для кінцевого порту функціонує так само, як і для проміжних портів [9].

3 урахуванням першої i другої технологій третя модель вантажоперевезень описується такою системою диференціальних рівнянь:

$$
\left\{\begin{array}{c}
\dot{z}_{0}(t)=\psi_{1}(t)-\alpha z_{0}+\alpha z_{1}+\varphi_{0}\left(z_{0}\right), \quad t \in[0,+\infty) \\
\dot{z}_{i}(t)=\alpha z_{i-1}-2 \alpha z_{i}+\alpha z_{i+1}+\varphi\left(z_{i}\right), \quad i=1,2, \ldots, m, t \in[0,+\infty) \\
\dot{z}_{m+1}(t)=\alpha z_{m}-\alpha z_{m+1}-\varphi_{2}(t)+\varphi\left(z_{m+1}\right), \quad t \in[0,+\infty) \\
z_{i}(t)=z_{i+1}(t+\tau), \quad i=1,2, \ldots, m, t \in[0,+\infty)
\end{array}\right.
$$

Клас рішень системи (8) такожнадзвичайно вузький, тому для опису реалізовуваних вантажоперевезень використовується квазі-рішення (є розриви в точках, кратні характеристиці системи контролю) типу біжучої хвилі.

Для початкових даних а $>0, \bar{i} \in\{0,1, \ldots, m+1\}$, початкового моменту часу $\bar{t} \in[0,+\infty)$, характеристик $\tau$, що задовольняють умові $0<\tau<\bar{\tau}$, (рис. 2 ), функції $\psi_{1}(\cdot) \in C^{\infty}([0, \tau], R)$ і $\psi_{2}(\cdot) \in C([0, \tau], R) \quad \epsilon$ єдині кусково-неперервні продовження функцій $\psi_{1}(\cdot)$ і $\psi_{2}(\cdot)$ та відповідне їм квазі-рішення $\left\{z_{i}(\cdot)\right\}_{0}^{m+1}$ типу біжучої хвилі 3 характеристикою $\tau$ системи (8) у фазовому просторі $K_{2 \propto}^{1}, \mu \in\left(\mu_{1}(\tau), \mu_{2}(\tau)\right)$, які задовольняють початковій умові $z_{\bar{i}}(\bar{t})=a$. Таке квазі-рішення є єдиним і неперервно залежить від початкової умови $a$ та функцій $\psi_{1}(\cdot)$ і $\psi_{2}(\cdot)$.

Така сама умова справедлива i для моделі 3 виділеним початковим портом відправки вантажів, за допомогою різкої зміни числа вузлів у початковому порту в початковій період часу можна організувати контрольований вантажопотік (отримати $\varepsilon$-квазірішення).

Для початкових даних а>0, $\bar{i} \in\{0,1, \ldots, m+1\}$, початкових моментів часу $\bar{t} \in[0,+\infty)$, характеристик $\tau$, що задовольняють умові $0<\tau<\bar{t}$, довільних функцій $\quad \psi_{1}(\cdot) \in C^{\infty}([0, \tau], R) \quad$ і $\quad \psi_{2}(\cdot) \in C([0, \tau], R)$ та випадкового $\varepsilon>0$ існує функція $\psi_{1 \varepsilon}(\cdot)$ $\in C^{\infty}([0, \tau], R)$, відмінна від $\psi_{1}(\cdot)$ в околі точки 0 , така, що продовження функцій $\psi_{1 \varepsilon}(\cdot)$ і $\psi_{2}(\cdot)$ на $\left(\tau,+^{\circ}\right)$ та відповідне їм квазі-рішення $\left\{z_{i \varepsilon}(\cdot)\right\}_{0}^{m+1}$ типу біжучої хвилі 3 характеристикою $\tau$ системи (8) задовольняє умові $z_{i \varepsilon}(\bar{t})=a$, належить фазовому простору $K_{2 \propto}^{1}$ при $\mu \in\left(\mu_{1}(\tau), \mu_{2}(\tau)\right)$ і $€(\varepsilon, \tau)$-квазі-рішенням моделі вантажоперевезень 3 виділеним початковим портом відправлення вантажів [10].

\section{4. Модель вантажоперевезень по круговому} ланцюжку портів

Модель вантажоперевезень по круговому ланцюжку портів

Четверта модель є частковим варіантом першої моделі й описує транспортні вантажоперевезення по круговому ланцюгу з $n$ портів. Для дослідження такої моделі необхідне рішення системи (3)-(4), що задовольняє такій додатковій умові:

$$
z_{i}(t)=z_{i+n}(t), i \in Z, t \in[0,+\infty) .
$$

Таким чином, ця модель описується такою системою: 


$$
\left\{\begin{array}{c}
\dot{z}_{i}(t)=\alpha z_{i-1}-2 \alpha z_{i}+\alpha z_{i+1}+\varphi\left(z_{i}\right), \quad i \in Z, t \in[0,+\infty) ; \\
z_{i}(t)=z_{i+n}(t) \quad i \in Z, t \in[0,+\infty) \\
z_{i}(t)=z_{i+1}(t+\tau), \quad i \in Z, t \in[0,+\infty)
\end{array}\right.
$$

Якщо $\left\{\bar{z}_{i}(\cdot)\right\}_{i \in Z} \in$ рішенням системи (9), то для $\mathrm{i}$ $\in Z$ функція $\bar{z}_{i}(\cdot)$ періодична 3 періодом $\tau_{\mathrm{n}}$.

Вирішення системи (9) залежить від розв'язання такої системи:

$$
\begin{gathered}
\dot{z}_{1}(t)=\alpha z_{n}-2 \alpha z_{1}+\alpha z_{2}+\varphi\left(z_{1}\right), \quad t \in[0,+\infty) ; \\
\dot{z}_{i}(t)=\alpha z_{i-1}-2 \alpha z_{i}+\alpha z_{i+1}+\varphi\left(z_{i}\right) \quad i \in 2, \ldots, n-1, t \in[0,+\infty) \\
\dot{z}_{n}(t)=\alpha z_{n-1}-2 \alpha z_{n}+\alpha z_{1}+\varphi\left(z_{n}\right), \quad t \in[0,+\infty) \\
\left\{\begin{array}{c}
z_{i}(t)=z_{i+1}(t+\tau), i \in 1, \ldots, n-1, t \in[0,+\infty) \\
z_{n}(t)=z_{1}(t+\tau), \quad t \in[0,+\infty)
\end{array}\right.
\end{gathered}
$$

Якщо система (10)-(11) має рішення, то воно буде періодичним з періодом $\tau_{\mathrm{n}}$. Одним $з$ таких рішень $є$ стаціонарне рішення $(\Delta, \Delta, \Delta \ldots, \Delta)$. Для пошуку інших рішень (якщо вони існують) потрібні всі рішення системи диференціальних рівнянь (1) (тобто рішення типу біжучої хвилі, що задовольняють умовам (11)).

Для довільних $\alpha>0, \delta>0$ всі рішення системи диференціальних рівнянь (10) 3 координатами початкового значення, більшими 0, обмежені. Більше того, кожна координата рішення знизу обмежена нулем, а зверху асимптотично обмежена значенням $\Delta$.

Стаціонарне рішення $(\Delta, \Delta, \ldots, \Delta)$ системи диференціальних рівнянь (10) є локально стійким за Ляпуновим у першому наближенні [11].

Для визначення області стійкості вказаного рішення система диференціальних рівнянь (10) вирішена чисельно за допомогою методу Рунге-Кутта 4-го порядку.

Для $\alpha>0$ і $\delta>0$ область стійкості стаціонарного рішення $(\Delta, \Delta, \ldots, \Delta)$ системи диференціальних рівнянь (10) 3 додатними координатами початкового значення зводиться до стаціонарного рішення системи рівнянь $(\Delta, \Delta, \ldots, \Delta)$.

3 вищевказаного витікає, що рішення системи диференціальних рівнянь (10) 3 додатними координатами початкового значення обмежено; більше того, воно зводиться до стаціонарного рішення $(\Delta, \Delta, \ldots, \Delta)$. Отже, інших періодичних рішень, крім стаціонарного рішення $(\Delta, \Delta, \ldots, \Delta)$, система диференціальних рівнянь (10) 3 додатними координатами початкового значення не має. Це, своєю чергою, означає, що система (10)-(11) з додатними координатами початкового значення, крім стаціонарного рішення $(\Delta, \Delta, \ldots, \Delta)$, не має інших рішень. Таким чином, вихідна система (9) 3 додатними координатами початкового значення має єдине рішення типу біжучої хвилі, а саме стаціонарне рішення $(\Delta, \Delta, \ldots, \Delta)$.

Наведений підхід до розв'язання транспортної задачі може бути використаний також під час розв'язання інших завдань, що не належать до вантажоперевезень. У цьому разі змінні, які визначають ефективність, мають різний зміст залежно від конкретного завдання.

Тобто транспортну задачу можна застосувати в будь-якому процесі як у виробництві, так і для оптимізації процесів обробки даних. А вживання методів оптимізації застосованих у всіх моделях вантажоперевезень, які присутні в бібліотеках Mashine Learning, допомагає виключати 3 розрахунків оптимізації людину і знизити іiі роботу до мінімуму за допомогою комп'ютерної оптимізації [10].

\section{ВИСНОВКИ}

Якщо підбити підсумки статті, то можна сказати, що тип вантажоперевезень вибирається системою на основі поставленої задачі перевезення вантажу. Після цього комп'ютер обирає потрібний алгоритм для побудови маршруту й завантаження вантажу для оптимального вантажоперевезення.

\section{Список літератури:}

[1] Канторович Л.В. Математические методы организации и планирования производства. Ленинград : Изд-во ЛГУ, $1939.68 \mathrm{c}$.

[2] Канторович Л.В., Гавурин М.К. Применение математических методов в вопросах анализа грузопотоков. Проблемь повьщиения эффективности работы транспорта: Сб. научн. статей. Москва : Изд-во АН СССР, 1949. С. 110-138.

[3] Данциг Дж., Вольф Ф. Алгоритм разложения для задач линейного программирования. Математика: Сб. переводов, 1964. T. 8. № 1. С. $151-160$.

[4] Лурье А.Л. Алгоритм решения сетевой транспортной задачи с ограничением пропускных способностей методом условно-оптимальных планов. Мат-лы конф. по опыту и перспективам применения математических методов и ЭММ в планировании. 1962. С. 3-13.

[5] Авен О.И., Ловецкий, С.Е., Моисеенко, Г.Е. Оптимизация транспортных потоков. Москва : Наука. 1985. 166 с.

[6] Галабурда В. Г. Оптимальное планирование грузопотоков. Москва : Транспорт. 1985. 256 с.

[7] De Jong G., Gunn H.F., Walker W. National and international freight transport models: Anoverview and ideas for further development. Transport Rev. 2004. Vol. 24. No. 1. P. 103-124.

[8] Beklaryan L.A., Khachatryan N.K. Traveling wave type solutions in dynamic transport models. Functional Differential Equations. 2006. Vol. 13. No. 2. P. 125-155.

[9] Yamada T., Russ B.F., Castro J., Taniguchi E. Designing multimodal freight transport networks: A heuristic approach and applications. Transportation Sci. 2009. Vol. 43. No. 2. P. 129-143.

[10] Левин Д.Ю. Моделирование процессов перевозки. Мир транспорта. 2010. Т. 8. № 5(33). С. 48-55.

[11] Бекларян Л.А., Хачатрян Н.К. Об одном классе динамических моделей грузоперевозок. Журнал вычислительной математики и математической физики. 2013. Т. 53. № 10. С. 1649-1667. 